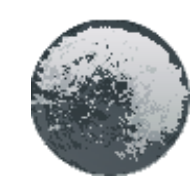

\title{
SECONDARY SCHOOL STUDENTS' ATTITUDES TOWARDS LEARNING CHEMISTRY: COMPARISON BY GENDER, AGE AND EDUCATIONAL STREAM
}

\author{
Mehboob UI Hassan, Ammara Murtaza \\ University of the Punjab Lahore, Pakistan
}

\begin{abstract}
There is a dilemma among secondary school students' attitudes towards learning chemistry in public sector educational institutions. Chemistry is considered as complicated and painstaking subject for students. Research was conducted to explore students' attitudes towards learning chemistry of public sector secondary school students of district Lahore. Researchers used quantitative research approach based on positivist paradigm through conducting survey. Sample consisted of randomly selected enrolled 700 secondary school students: 350 male and 350 female. Questionnaire was administered to measure students' attitudes based on 5-point Likert type options. Content validity of the instrument was confirmed from three expert opinions, and reliability was measured by calculating Cronbach's Alpha Scores .841. Normality of the data was confirmed by calculating Shapiro-Wilk's test, $p>.05, n<2000$. Data were analyzed in SPSS by calculating independent sample t-tests and one-way ANOVA. Findings revealed significant difference between students' attitudes towards learning chemistry by gender and no significant difference was found between science and computer science streams. Findings further revealed that students having 14-15 years of age have more attitudes towards learning chemistry as compared to students having 15-16 and 16-17 years of age. It is recommended that female secondary school teachers need to organize classroom activities to arouse female students' interest towards learning chemistry. Teachers during delivering lectures need to concentrate on students' cognitive level and age group. They feel themselves as teenagers because 10th grade students have less understanding regarding chemistry. Heads of the institutions should check teachers' and students' classroom activities as well.
\end{abstract}

Keywords: educational stream, learning chemistry, secondary level, students' attitudes.

\section{Introduction}

Present era is the explosion of knowledge at mass level and has disclosed the mysteries of universe. Today's man is living in entire new world. New knowledge has doubled within short period of time. Transfer of old and new knowledge to younger generation has become important than past. Education refines soul and body to teach individuals the art of living. It updates modern societies and facilitates national development with the help of science. According to Khalick et al. (1998) science has been a long held phenomenon for educationists since decades. Science is a difficult, dynamic and multifaceted concept (Eflin et al., 1999; Khalick \& Lederman, 2000). Science is a hypothetical and practical way to understand nature of scientific phenomenon (Lederman et al., 2002). Science is the understanding of natural world working around us. It is a logical approach to discover how things work. Science focuses on practical, inferential and innovative processes. Science is the intellectual heritage of human beings that has come down to humanity. It is the body of knowledge and collection of facts that discover new knowledge and input to the existing knowledge (Capaldi \& Proctor, 2005). Science is an attribute of different human actions. Science has covered various key aspects of human understanding (Fusco, 2001). Man has 
become aware of his surroundings he started pondering over the natural phenomena and found himself engulfed. It is one of the facts that knowledge of science is productive and state for a better life (Barton, 2001).

Science education has diversity in its context globally and focused at enhancing scientific literacy among human beings in modern era (Michie et al., 2018; Taber, 2018). Science education increases students' effectiveness and ongoing development of the country. It makes students responsible citizens, actively engaged in their learning processes (Barab \& Luehmann, 2003), enables students' creativity and innovative thinking and enhances critical thinking and problem-solving skills. It makes students aware about complex challenge of societies (Haney \& McArthur, 2002) and develops their scientific understanding and its applications (Grandy \& Duschl, 2007; Stanovich, 2003). It develops students' understanding about Science, Technology, Society and Environment; STSE. Science education has obtained a secured place all over the world (Spillane et al., 2001). Today individuals are familiar about the awareness of science and technology (Barmby et al., 2008).

Individual's motivation, beliefs, aptitude and attitudes have been playing an important role in the progress of science and technology. These constructs have been remaining researchable for researchers (Abidin et al., 2012; Clément \& Vallerand, 2000; Dornyei, 1990; Gardner, 1975; Noels et al., 2012). Attitude refers to unobservable inner situation of human beings (Cheung, 2009). Attitudes are students' beliefs that facilitate learning and effect on the selection of subjects, area of interest, academic achievements and logical understanding (Yara, 2009). Attitudes exert pivotal influence on students' understanding and are tendencies that react towards positivity or negativity (Kaiser \& Schultz, 2009). Individual's attitudes are measured by using different measurement attitudinal scales (Eagly \& Chaikn, 1998). Positive attitudes foster learning of subjects and facilitate teaching learning process (Festus, 2012). Negative attitude badly affects teaching learning, detracts students from their studies and students obtain lower marks in their exams (Cheung, 2009). Empirically literature reported that students possess attitudes towards Physics, Biology, Mathematics and Chemistry (Barnes et al., 2005; Murphy \& Whitelegg, 2006; Osborne \& Collins, 2001).

Concept of attitudes about science; Chemistry is merely to some extent vague, weakly expressed, unformulated and tenuous (Osborne et al., 2003). Students' attitudes towards learning chemistry fueled a lot of special tasks of the research from a long time ago (Gräber, 2002; Gilbert, 2006). Students' attitudes towards learning chemistry play a crucial role in helping their opinions and judgments (Abidin et al., 2012), have a significant effect on students' learning chemistry (Salta \& Tzougraki, 2004) and enhance students' confidence in practical life. Negative attitudes create hurdles in students' understanding and become students' weak, dull and mind numbing in their class (Eze \& Agboma, 2008), reduce students' concentration, keenness and badly affect students' enrollment (Adesoji $\&$ Raimi, 2004). Teachers develop positive attitudes among students as they enhance students' behavior (Glasman \& Albarracín, 2006). Those students who have destructive attitudes obtain low marks in their achievements (Bennett, 2001).

Students have poor content and practical knowledge of chemistry. They have less understanding about basic concepts of chemistry and show passive and inactive involvements towards learning chemistry (Aiken \& Aiken, 1969). Students show their poor intentions toward schools' enrollment. This decline level of poor enrollment in secondary schools towards subject of chemistry is enhancing gradually (Hofstein \& 
Mamlok-Naaman, 2011; Salta \& Tzougraki, 2004). Studies reported mismatch between students' cognitive abilities and demands of curricula at different educational levels (Adey \& Shayer, 1994; Iqbal, 1997). This mismatch put significant effect on students' attitudes towards learning chemistry (Adey \& Shayer, 1994). Studies reported significant effect of male and female students' attitudes towards learning chemistry, having science, arts and computer science streams enrolled in public and private secondary schools (Cheung, 2009; Usman \& Memah 2007; Usman \& Ubah, 2007).

Usman and Memah (2007) explored that male students have better attitudes towards learning chemistry as compared to female students. Male students have more concentration towards laboratory work and show better performance in laboratory activities. They are eager to perform practical work independently (Adesoji \& Raimi, 2004; Wong \& Fraser, 1996). Female students have better attitudes as compared to male students (Anditi \& Okere, 2013). Female students are more motivated towards biological sciences as compared to male students (Stark \& Gray, 1999; Warrington \& Younger, 2000). Literature reported that male and female students have constructive / destructive attitudes towards learning chemistry (Adesoji \& Raimi, 2004; Barnes et al., 2005; Cheung, 2009; Harvey \& Stable, 1986).

Harvey and Stable (1986) conducted a research in England on sample of 2,311 male and female students. Researchers investigated secondary school students' attitudes towards Biology, Chemistry, Physics, Science and School. Findings reported that male students have more attitudes as compared to female students towards learning chemistry. Barnes et al. (2005) conducted research in Australia; Sydney in three public and two private high schools on sample of 449 respondents; 223 boys and 226 girls having 7-10 years of age. Researchers employed three questionnaires to collect data from the respondents. Findings declare that male have better attitudes towards chemistry as compared to female students.

Cheung (2009) planned quantitative study to explore students' attitudes towards chemistry on a sample of 954 male and female students enrolled in different grades having 16 to 19 years of age. Self-developed questionnaire consisting of 12-items was used based on four subscales categorized in 7-point Likert type options. Collected data were analyzed in SPSS by employing MANOVA to measure the interaction results on male and female students of different grades. Findings revealed that students' attitudes towards learning chemistry have significant difference regarding their age groups, $(F(4,941)=5.145, p<$ $.05)$ and students' grades $(F(12,2490)=2.587, p<.05)$.

Adesoji and Raimi (2004) conducted quantitative research to find out the influence of laboratory instructions applying problem solving strategies on students' attitudes towards chemistry in eight co-educational schools of Oyo state, Nigeria. Researchers selected sample of 282 students: 141 boys and 141 girls having 12 to 16 years of age groups. Researchers used quasi-experimental research design applying $4 \times 2 \times 2$ factorial representations. Data were collected through administering Chemistry Practical Skills Rating Scale; SPSRS and Chemistry Attitude Inventory; CAI from respondents. Validated version of SPSRS had already used in other studies (Adeoye, 2000; Raimi, 2000). Reliability of three factors was confirmed by calculating Cronbach's Alpha Score .79, .87 and .71 respectively. Reliability of CAI was confirmed through applying Cronbach's Alpha Score .89. Collected data were analyzed in SPSS calculating ANCOVA applying descriptive statistics. Findings revealed that laboratory instructions put positive significant influence on students' attitudes towards learning chemistry. Results further declared that male students possessed greater attitudes $(M=84.71)$ as compared to female students $(M=82.91)$. 
Teaching and learning process enables students' vigilance in the field of science. This teaching and learning process is being made with the development of secondary school students' scientific attitudes (Durant et al., 1989; Iqbal, 1997; Jenkins, 1994; Miller et al., 1997). Teaching and learning in providing constructive education is not (apparent) plain as the nose on face (Arslan \& Akbarov, 2012; Kind et al., 2007; Koballa \& Crawley, 1985). Students make their contributions and take part in the betterment of superiority in scientific world (De Vos, et al., 2002). In Pakistani context, science is used as an umbrella term under which subjects of Physics, Chemistry, Biology and Mathematics fall. General science is taught as a compulsory subject from grade 1 to 8 students in integrated form. Students of 9th grade choose different educational streams: Physics, Chemistry and Biology; Physics, Chemistry and Computer science, and arts stream (Government of Pakistan, 1959, 1992; 1998-2010, \& 2009; Iqbal et al., 2009). This division prolongs reaching on intermediate level; 11th and 12th, after passing secondary school certificates from Pakistani educational institutions. Teachers are nation builders to transmit plethora of information managing their perceived abilities. Pakistani secondary school teachers teach Physics, Chemistry, Biology and Mathematics to 9th and 10th grade students. There is deficiency of teaching and learning towards Chemistry at secondary level in public sector schools (Holbrook, 2005). It has been given great concern towards the pedagogy and content of chemistry from the past few decades. Teachers concentrate on logical, meaningful, authentic, relevant and contextualized directions of chemistry education to transform knowledge of chemistry (Hofstein \& Kesner, 2006; Finch, 2008; Holbrook, 2005; Holbrook \& Rannikmae, 2007; Cheung, 2009). Teachers motivate secondary school students to develop scientific attitudes for all science subjects: Mathematics, Physics, Chemistry and Biology. Chemistry is taught as a compulsory subject in secondary schools of Punjab, province of Pakistan. School level programs are planned to develop students' logical thinking. Teachers enhance students' understanding towards learning chemistry. The contents and methodology of chemistry incorporate numerous theoretical and practical aspects. These aspects provide additional wisdom towards learning chemistry. Topics of chemistry are interlinked with configuration of matter and substance that proved to be more difficult subjects for students (Sirhan, 2007). It is compulsory to produce scientists in every walk of life to make a revolt in every society. Today importance of chemistry centers from the mounting decline among secondary school students (Smithers \& Robinson, 1988). Focusing the importance of chemistry, researchers are eager to explore 10th grade students' attitudes towards learning chemistry. Ultimate purpose of this research was to explore students' attitudes towards learning chemistry regarding their gender, age and educational stream; science and computer science stream students enrolled in public sector secondary schools of Punjab province.

\section{Research Methodology}

\section{General Background}

Research methodology deals with the method and procedure of the research followed in a logical manner. Research was descriptive in nature and quantitative research approach leading to positivist paradigm was applied to explore a burning dilemma. Population of the study consisted of 353,382 male and female enrolled students in session 2017-2018 of public sector secondary schools of district Lahore, Punjab-Province of Pakistan. 


\section{Sample Selection}

To select the sample of present research, researchers obtained a list of secondary schools from Punjab Education Department district Lahore. The list included a number of 10th grade students enrolled in public sector secondary schools of district Lahore. Researchers randomly selected 10 male and 10 female public sector secondary schools. From selected 20 secondary schools, researchers selected 700 students applying DIJ and Hotjar's quantitative research calculating sample size criteria. Sample of respondents consisted of 14 to 17 years of age group students enrolled in science and computer science educational streams.

\section{Instrumentation and Procedure}

After a review of literature, observational studies and expert opinions, researchers' self-constructed questionnaire to obtain students' attitudes towards learning chemistry using 5-point Likert type responses was based on strongly agree, agree, undecided, disagree and strongly disagree. Likert type responses are best options that accurately measure respondents' attitudes towards a prescribed construct (Amina, 2016; Bryman, 2012; Cohen et al., 2007; Hassan \& Akbar, 2016; Rashid \& Gao, 2012). Initial questionnaire consisted of seven parts; Part A comprised of demographic information; students' gender, age, name of institution and Part B; comprised of six subscales; students' knowledge towards chemistry 5-items, laboratory activities 5-items, emotional aspects 6-items, cognitive aspects consist of 5-items, environmental aspects 6-items, and students' general attitudes towards learning chemistry also consist of 5-items. Initial questionnaire was validated from experts. Validity of instrument confirms correctness, meaningfulness and usefulness of items from obtained data (Burns \& Grove, 2005; Scheaffer \& Smith, 2007). Validity of the questionnaire was confirmed from educational psychologists, English language experts and subject specialists. Experts confirmed the preferred items to ensure the content validity of the instrument. Initial questionnaire was pilot tested on small sample of 200 secondary school students: 100 male and 100 female. Two items were excluded because these items were incomprehensible and beyond the understanding of students. Final instrument consisted of 30 -items. Factor wise reliability of the instrument was confirmed by calculating Cronbach's Alpha score given below:

\section{Table1}

Factor wise Cronbach's alpha reliability statistics

\begin{tabular}{clcc}
\hline No. & \multicolumn{1}{c}{ Factors } & Items & Cronbach's Alpha \\
\hline 1 & Students' knowledge about chemistry & 5 & .85 \\
2 & Assessment of laboratory & 5 & .89 \\
3 & Emotional aspects regarding learning chemistry & 5 & .78 \\
4 & Cognitive aspects regarding learning chemistry & 5 & .88 \\
5 & Environmental aspects regarding learning chemistry & 5 & .75 \\
6 & General attitudes towards chemistry & 5 & .81 \\
\hline
\end{tabular}


Researchers assured ethical considerations: informed consent, confidentiality, anonymity, physical and psychological harm from respondents during data collection. Researchers distributed 700 copies among respondents. Students were instructed in their classrooms. Respondents were inculcated regarding each statement in this regard. Normality of data was confirmed by Shapiro-Wilk's test, $p>.05, n<2000$.

\section{Table 2}

Tests of normality

\begin{tabular}{clcccccc}
\hline \multirow{2}{*}{ No } & \multirow{2}{*}{ Name of variables } & \multicolumn{3}{c}{ Kolmogorov-Smirnov ${ }^{\mathbf{a}}$} & \multicolumn{3}{c}{ Shapiro-Wilk's } \\
& & $K-S$ & $d f$ & $p$ & $S-W$ & $d f$ & $p$ \\
\hline 1 & Students' gender & .342 & 698 & .01 & .637 & 698 & .550 \\
2 & Educational stream & .366 & 698 & .01 & .633 & 698 & .083 \\
3 & Students' age & .269 & 698 & .01 & .781 & 698 & .610 \\
4 & Chemistry knowledge & .095 & 698 & .01 & .968 & 698 & .334 \\
5 & Laboratory activities & .071 & 698 & .01 & .982 & 698 & .505 \\
6 & Emotional aspects & .083 & 698 & .01 & .980 & 698 & .603 \\
7 & Cognitive aspects & .085 & 698 & .01 & .968 & 698 & .521 \\
8 & Environmental aspects & .083 & 698 & .01 & .972 & 698 & .211 \\
9 & General attitudes & .093 & 698 & .01 & .980 & 698 & .312 \\
\multicolumn{2}{l}{ a. Lilliefors Significance Correction } & & & & & & \\
\hline
\end{tabular}

Normally distributed data provide concrete directions for applying parametric and non-parametric data analysis techniques (Corder \& Foreman, 2009; Elliott \& Woodward, 2007; Öztuna et al., 2006; Singh \& Masuku, 2014). Collected data were entered in SPSS for applying statistical techniques. Data were analyzed by calculating independent sample $t$-test and one-way ANOVA to find out students' gender, educational streams and age wise significant difference between secondary school students' attitudes towards learning chemistry.

\section{Research Results}

This part improvised data analysis by applying statistical techniques in SPSS. The possible responses of each statement obtained through attitude scale were assigned on 5-point Likert scale. Data analysis and its interpretation are given below: 


\section{Table 3}

Students' attitudes towards learning chemistry by gender and educational streams

\begin{tabular}{llccccccc}
\hline Variables & \multicolumn{1}{c}{ Categories } & $\boldsymbol{N}$ & $\boldsymbol{M}$ & $\boldsymbol{S D}$ & $\boldsymbol{d f}$ & $\boldsymbol{F}$ & $\boldsymbol{t}$ & $\boldsymbol{p}$ \\
\hline \multirow{2}{*}{ Gender } & Male & 350 & 99.363 & 21.261 & & & & \\
& Female & 350 & 93.077 & 19.650 & & & & \\
& Science & 385 & 93.691 & 19.501 & & & & \\
\multirow{2}{*}{ Stream } & & & & & 698 & 4.602 & 3.605 & .062 \\
& Computer Science & 315 & 99.311 & 21.704 & & & & \\
\hline
\end{tabular}

As delineated in Table 3, independent samples t-test was applied to compare male and female students' attitudes towards learning chemistry enrolled in science and arts streams. Results show significant difference between students' attitudes towards learning chemistry by gender, $t(698)=4.083, p<.01$; male students have more constructive attitudes $(M=99.363, S D=21.261)$ towards learning chemistry as compared to female students $(M=93.077, S D=19.650)$ and found no significant difference between their educational stream, $t(698)=3.605, p>.05$; science students have about equal attitudes $(M=93.691, S D=19.501)$ as compared to computer science students $(M=99.311, S D=$ 21.704) towards learning chemistry. 


\section{Table 4}

Factor wise students' attitudes towards learning chemistry by gender and educational stream

\begin{tabular}{|c|c|c|c|c|c|c|c|c|c|c|}
\hline No. & Name & & Gender & $N$ & $M$ & $S D$ & $d f$ & $F$ & $t$ & $p$ \\
\hline & \multirow{2}{*}{\multicolumn{2}{|c|}{$\begin{array}{l}\text { Emotional factor for } \\
\text { learning chemistry }\end{array}$}} & Male & 350 & 10. & , & \multirow{2}{*}{698} & \multirow{2}{*}{1.70} & & \multirow{2}{*}{.03} \\
\hline & & & & 350 & 11.137 & 3.389 & & & & \\
\hline \multirow{2}{*}{2} & \multirow{2}{*}{\multicolumn{2}{|c|}{$\begin{array}{l}\text { Students' knowledge about } \\
\text { chemistry }\end{array}$}} & & 350 & 11.169 & 3.150 & \multirow{2}{*}{698} & \multirow{2}{*}{1.91} & \multirow[b]{2}{*}{6} & \multirow{2}{*}{.17} \\
\hline & & & & 350 & 9.669 & 3.423 & & & & \\
\hline \multirow{2}{*}{3} & \multirow{2}{*}{$\begin{array}{l}\text { Assessment of laboratory } \\
\text { activities }\end{array}$} & & & 350 & 12.357 & 3.424 & \multirow{2}{*}{698} & \multirow[b]{2}{*}{0.22} & \multirow[b]{2}{*}{4.66} & \multirow[b]{2}{*}{.64} \\
\hline & & & & 350 & 11.123 & 3.580 & & & & \\
\hline \multirow{2}{*}{4} & \multirow{2}{*}{$\begin{array}{l}\text { Cognitive factor for learning } \\
\text { chemistry }\end{array}$} & & $\mathrm{Ma}$ & 350 & 11.589 & 3.542 & \multirow{2}{*}{698} & \multirow{2}{*}{1.31} & \multirow{2}{*}{5.76} & \multirow{2}{*}{.25} \\
\hline & & & Fen & 350 & 10.011 & 3.705 & & & & \\
\hline \multirow{2}{*}{5} & \multirow{2}{*}{\multicolumn{2}{|c|}{$\begin{array}{l}\text { Environmental factors for } \\
\text { learning chemistry }\end{array}$}} & $\mathrm{Ma}$ & 350 & 11.771 & 3.941 & \multirow{2}{*}{698} & \multirow{2}{*}{0.12} & \multirow{2}{*}{2.64} & \multirow{2}{*}{.73} \\
\hline & & & er & 348 & 10.980 & 3.992 & & & & \\
\hline \multirow[b]{2}{*}{6} & & & $\mathrm{M}$ & 350 & $11 .^{7}$ & 3.450 & & & & \\
\hline & chemistry & & & 0 & 1 & 3.716 & 98 & 92 & 1.30 & .17 \\
\hline & Em & & & 38 & 9. & 5 & & & & \\
\hline 1 & & & & 315 & 11.019 & 3.206 & & & & \\
\hline 2 & Stude & & Science & 385 & 11.127 & 3.499 & & & & \\
\hline 2 & chemistry & & & 315 & 12.489 & 3.483 & & IIIJ & & \\
\hline 3 & Asse & & & 385 & 11.164 & 3.328 & & & & \\
\hline 3 & . & & & 315 & 10.949 & 3.012 & 698 & 12 & 0.88 & .113 \\
\hline 4 & Cognitive factor $\mathrm{f}$ & & ce & 385 & 10.073 & 3.649 & & & & \\
\hline & & & & 315 & 11.689 & 3.588 & & +3 & & \\
\hline 5 & Envirc & E్ & & 383 & 11.018 & 3.922 & & & & \\
\hline & & & & 315 & 11.813 & 4.021 & 698 & 12 & 2.63 & \\
\hline & Gene & $E$ & Science & 385 & 11.366 & 3.641 & & & & \\
\hline 0 & & & $\begin{array}{l}\text { Com } \\
\text { Sci }\end{array}$ & 315 & 11.794 & 3.512 & 698 & .187 & 1.57 & .666 \\
\hline
\end{tabular}

As revealed in Table 4, independent samples t-test was conducted to compare male and female students' attitudes towards learning chemistry on different factors. Interpretation shows significant difference between male and female secondary school students' attitudes against: emotional factors for learning chemistry, $t(698)=.58, p<.05$, female students had better attitudes $(M=11.137, S D=3.389)$ as compared to male students $(M=10.997, S D=$ 2.980), no significant difference was present against factor regarding: students' knowledge about chemistry, $t(698)=6.03, p>.05$, assessment of laboratory activities, $t(698)=4.66$, $p>.05$, cognitive factor for learning chemistry, $t(698)=5.76, p>.05$, environmental factors for learning chemistry, $t(698)=2.64, p>.05$ and students' general attitudes towards learning chemistry, $t(698)=1.30, p>.05$. Analysis further reported no significant difference between secondary school students' attitudes towards learning chemistry in terms of various factors. It is assured that science and computer science students have about same attitudes against factors regarding: students' knowledge about chemistry, $t(698)=4.32$, 
$p>.05$, assessment of laboratory activities, $t(698)=5.13, p>.05$, emotional factors for learning chemistry, $t(698)=.88, p>.05$, cognitive factors for learning chemistry, $t(698)$ $=5.87, p>.05$, environmental factors for chemistry learning, $t(698)=2.63, p>.05$ and students' general attitudes towards learning chemistry, $t(698)=1.57, p>.05$.

\section{Table 5}

One-way ANOVA on students' age group

\begin{tabular}{lccccc}
\hline & Sum of Squares & $\boldsymbol{d f}$ & Mean Square & $\boldsymbol{F}$ & $\boldsymbol{p}$ \\
\hline Between Groups & 15929.297 & 2 & 7964.648 & & \\
Within Groups & 283498.823 & 698 & 406.741 & 19.582 & .01 \\
Total & 299428.120 & 700 & & & \\
\hline
\end{tabular}

As ascertained in Table 4, one-way ANOVA was applied to find significant difference between students 14-15, 15-16 and 16-17 years of age. Output shows significant difference between secondary school students' attitudes towards learning chemistry by their age, $(F$ $(2,697)=19.582, p<.01)$. It is reported that students' attitudes towards learning chemistry vary according to their age group. In educational institutions of Pakistan secondary school students are enrolled with different age groups. To explore further age wise difference between students' attitudes towards learning chemistry, Tukey Post Hoc test was employed.

Table 6

Tukey Post Hoc on students' age group

\begin{tabular}{|c|c|c|c|c|c|c|c|}
\hline Students' age & $N$ & $M$ & $S D$ & (J) Age & $M D$ & $S E$ & $p$ \\
\hline \multirow[b]{2}{*}{14 to 15 Years } & \multirow[b]{2}{*}{291} & \multirow[b]{2}{*}{100.18} & \multirow[b]{2}{*}{21.84} & 15 to 16 Years & $4.34060^{*}$ & 1.63981 & .08 \\
\hline & & & & 16 to 17 Years & $14.93401^{*}$ & 2.39265 & .01 \\
\hline \multirow[b]{2}{*}{15 to 16 Years } & \multirow[b]{2}{*}{315} & \multirow[b]{2}{*}{95.84} & \multirow[b]{2}{*}{17.94} & 14 to 15 Years & $-4.34060^{*}$ & 1.63981 & .08 \\
\hline & & & & 16 to 17 Years & $10.59341^{*}$ & 2.37029 & .01 \\
\hline \multirow[b]{2}{*}{16 to 17 Years } & \multirow[b]{2}{*}{94} & \multirow[b]{2}{*}{85.24} & \multirow[b]{2}{*}{21.80} & 14 to 15 Years & $-14.93401^{*}$ & 2.39265 & .01 \\
\hline & & & & 15 to 16 Years & $-10.59341^{*}$ & 2.37029 & .01 \\
\hline
\end{tabular}

As established in Table 6, Tukey Post Hoc test was applied to explore significant difference between students' age and attitudes towards learning chemistry. Results of analysis show significant difference between students having 14 to 15 and 15 to 16 years of age $(p=.008), 14$ to 15 and 16 to 17 years of age $(p=.001)$ and students having 15 to 16 and 16 to 17 years of age $(p=.001)$. 
Table 7

One-way ANOVA on factors of students' attitudes towards learning chemistry

\begin{tabular}{|c|c|c|c|c|c|c|c|c|c|c|}
\hline \multirow{2}{*}{ No } & \multirow{2}{*}{ Factors } & \multirow{2}{*}{$N$} & \multicolumn{2}{|c|}{$14-15$ years } & \multicolumn{2}{|c|}{$15-16$ years } & \multicolumn{2}{|c|}{$16-17$ years } & \multicolumn{2}{|c|}{ ANOVA } \\
\hline & & & $M$ & $S D$ & $M$ & $S D$ & $M$ & $S D$ & $F$ & $p$ \\
\hline 1 & Emotional a & 700 & 11.01 & 3.04 & 11.32 & 3.26 & 10.39 & 3.31 & 3.126 & .05 \\
\hline 2 & Students' knowledge & 700 & 11.14 & 3.25 & 10.26 & 3.24 & 8.73 & 3.54 & 19.709 & .01 \\
\hline 3 & Laboratory activities & 700 & 12.63 & 3.52 & 11.23 & 3.27 & 10.72 & 3.96 & 16.912 & .01 \\
\hline 4 & Cog & 700 & 0 & 3.59 & 10.53 & 3.23 & 8.60 & 4.42 & 30. & .01 \\
\hline 5 & Environme & 700 & 11.90 & 4.09 & 11.28 & 3.70 & 10.06 & 4.25 & 7.855 & .01 \\
\hline 6 & General attitudes & 700 & 11.95 & 3.52 & 11.09 & 3.36 & 11.90 & 4.31 & 4.904 & .01 \\
\hline
\end{tabular}

As ascertained in Table 7, results of One Way ANOVA show significant difference between secondary school students' attitudes towards learning chemistry in terms of: emotional aspects, $(F(2,698)=3.126, p<.01)$, students' knowledge, $(F(2,698)=19.709$, $p<.01)$, laboratory activities, $(F(2,698)=16.912, p<.05)$, cognitive aspects, $(F(2,698)=$ $30.501, p<.01)$, environmental aspects, $(F(2,698)=7.855, p<.01)$ and students' general attitudes towards learning chemistry, $(F(2,698)=4.904, p<.05)$. To explore further significant difference Tukey Post Hoc test was employed on factors regarding secondary school students towards learning chemistry.

Table 8

Tukey Post Hoc on factors regarding learning chemistry and students'age

\begin{tabular}{|c|c|c|c|c|c|c|c|c|}
\hline \multirow{2}{*}{ No } & \multirow{2}{*}{ Factors } & & \multicolumn{2}{|c|}{ 14-15 Years } & \multicolumn{2}{|c|}{ 15-16 Years } & \multicolumn{2}{|c|}{ 16-17 Years } \\
\hline & & & $15-16 \mathrm{Y}$ & $16-17 \mathrm{Y}$ & $14-15 \mathrm{Y}$ & $16-17 \mathrm{Y}$ & $14-15 \mathrm{Y}$ & $15-16 \mathrm{Y}$ \\
\hline 1 & Emotional aspects & & .240 & .101 & .240 & .014 & .101 & .014 \\
\hline 2 & Students' knowledge & & .001 & .001 & .001 & .001 & .001 & .001 \\
\hline 3 & Laboratory activities & $\stackrel{\varrho}{\Xi}$ & .001 & .001 & .001 & .220 & .001 & .220 \\
\hline 4 & Cognitive aspects & 党 & .001 & .001 & .001 & .001 & .001 & .001 \\
\hline 5 & Environmental aspects & & .056 & .001 & .056 & .009 & .001 & .009 \\
\hline 6 & General attitudes & & .003 & .910 & .003 & .053 & .910 & .053 \\
\hline
\end{tabular}

As established in Table 8, Tukey Post Hoc test was applied to explore further difference between students' age and factors regarding learning chemistry. Interpretation shows no significant difference between students having 14 to 15 years and 15 to 16 years of age $(p=.240), 14$ to 15 and 16 to 17 years of age $(p=.101)$ and significant difference existed between students having 15 to 16 and 16 to 17 years of age $(p=.014)$; report significant difference between students' knowledge about chemistry and students having 14 to 15 years and 15 to 16 years of age $(p=.001), 14$ to 15 and 16 to 17 years of age $(p$ $=.001)$ and 15 to 16 and 16 to 17 years of age $(p=.001)$; students' assessment regarding 
laboratory activities and students having 14 to 15 and 15 to 16 years of age $(p=.001), 14$ to 15 and 16 to 17 years of age $(p=.001)$ and no significant difference was found between students having 15 to 16 and 16 to 17 years of age $(p=.220)$; cognitive aspects regarding learning chemistry and students having 14 to 15 and 15 to 16 years of age $(p=.001), 14$ to 15 and 16 to 17 years of age $(p=.001)$ and 15 to 16 and 16 to 17 years of age $(p=.001)$; environmental factors regarding learning chemistry and students having 14 to 15 and 15 to 16 years of age $(p=.056)$, significant difference was present between students having 14 to 15 and 16 to 17 years of age $(p=.001)$ and 15 to 16 and 16 to 17 years of age $(p=.009)$ and also exists significant difference between students' attitudes towards learning chemistry and students having 14 to 15 and 15 to 16 years of age ( $p=.003)$, no significant difference was present between students having 14 to 15 and 16 to 17 years of age $(p=.910)$ and 15 to 16 and 16 to 17 years of age $(p=.053)$.

\section{Discussion}

Chemistry is considered a complicated subject for secondary school students and they have great intention towards its learning as well. Students comprehend various concepts of Chemistry at different grades. Students' conceptual understanding towards learning chemistry is associated with; teachers' content knowledge, nature of Chemistry curriculum and teachers' instructional methodologies used in chemistry classrooms (Cheung, 2009). Chemistry teaching and learning need concentration, techniques of motivation and innovative style of learning in classrooms. It is obvious that every student has his own preferences and choices for various instructional methodologies. Some students preferred student centered and several students desire teacher centered methodologies with incentive classroom environment (Hofstein \& Kesner, 2006). Chemistry classrooms' environments vary from place to place based on institutional facilities, teachers' pedagogical skills and students' intentions towards learning chemistry (Hofstein et al., 2004). Gender shows discrepancy towards learning chemistry at different grade levels. Male and female students remain curious and show significant difference towards learning chemistry (Osborne \& Dillon, 2008). This difference is due to different attitudinal variables: student-teacher relationship, students' interest for Chemistry subject, theory and practical, teachers' criteria of assessment and cognitive abilities towards learning chemistry.

Hofstein et. (1977) noticed gender differences towards learning chemistry in European higher secondary schools. Researchers adopted chemistry attitude scale for data collection constructed by Friedler and Tamir (1974). Findings revealed that gender has combined; constructive/destructive attitudes towards learning chemistry. Research exposed that female students possess more positive and constructive attitude toward learning chemistry as compared to male students because female students experienced more supportive and cooperative learning environment at schools. Female teachers show great attention towards students' learning chemistry. Female teachers having good experience and answer the questions of female students more comfortably as compared to male students (Bauer, 2002; Kahle, 1994; Koch, 2005; Urban, 2008). Findings of present research contradict with the findings of other studies (Barnes, Mclnerney, \& Marsh, 2005; Cheung, 2009; Harvey \& Stable, 1986; Hofstein et al., 1977; Shannon et al., 1982; Steinkamp \& Maehr, 1984) and align with the findings of the research conducted by Osborne and Dillon (2008). Results of present research revealed that male students possess more attitudes towards learning chemistry $(M=99.363, S D=21.261)$ as compared to female students $(M=93.077, S D=19.650)$. 
Cheung (2009) planned quantitative study on sample of 954 male and female students enrolled in secondary schools of different grades having 16 to 19 years of age in Hong Kong state. Data were analyzed in SPSS calculating MANOVA. Findings revealed that students having more years of age possess significant greater attitudes towards learning chemistry as compared to the students having less years of age. Findings of present research contradict with the findings of above research. Present research ascertained that students having less years of age possess more attitudes $(M=100.179, S D=21.838)$ towards learning chemistry as compared to students having more years of age $(M=85.248$, $S D=21.798)$. Students having less years of age are more curious towards learning science subjects. They remain eager towards understanding chemistry lessons in classrooms. Students' having less years of age indulge themselves in complete teaching and learning process and entirely concentrate on teachers' mimicking process performed in class. Their concentration enhances interest in practical performing subjects; Chemistry is one of them.

\section{Conclusions}

Scientific knowledge is the backbone of national development. Progress and advancement is the root of unbroken investigations and scientific discoveries. Scientific innovations are achieved by making compulsory acquisition of chemistry education. Chemistry is considered an imperative science subject and plays pivotal role in systematic innovation of universe. Researchers are working to examine, evaluate, access and analyze students' attitudes towards learning chemistry. Students consider chemistry as tough and complicated among science subjects. Complexity of this subject at secondary level creates negative attitudes towards learning chemistry. Students' negative attitudes towards learning chemistry create anxiety before exams and ultimately have poor effects on their academic achievement scores. In Pakistani public sector secondary schools Physics, Biology, Mathematics and Chemistry are considered difficult science subjects. Secondary school teachers try their best to arouse students' interests towards learning science subjects. It is common observation that students remain deprived in science subjects and obtain less academic achievement scores in these subjects. Our research shows that male secondary school students have positive attitudes towards learning chemistry. In Pakistani societies male students and teachers have strong mutual relations that strengthen positive relations between them. Hence male students are more encouraged to ask questions about concepts of chemistry. Male students have more access and spend maximum time in educational institutions with their teachers for the sake of learning. Students' interests towards learning chemistry also vary according to their age differences. In Pakistani educational institutions students are enrolled with 14 to 17 years of age in secondary level of education. Present research reports that students having more years of age possess greater interest towards learning chemistry. Students with more years of age have a strong understanding level towards learning chemistry. Teachers present clear picture of the importance of chemistry in classroom during the teaching learning process. Teachers maximize their potential and impart plethora of information on learning chemistry. They are well-aware from practical usage of chemistry in medicines, food, industry, health, cure of diseases etc. in daily routine matters. Resultantly mature students become eager towards learning chemistry and show interest in performing practical work in laboratories. Secondary education in Pakistan is based on three educational streams: science stream, computer science and arts stream. Present research states that students enrolled in science and computer science 
streams have about same attitudes towards learning chemistry. It is due to teachers' same instructional strategies, school facilities, laboratories and following alike curricula with medium of instructions. Present research recommends that teachers need to concentrate on students' cognitive abilities, female teachers should spare maximum time among students to build strong student teacher relationships. Head of the institutions should proper check and balance on teachers during lectures especially on students having more years of age groups.

\section{References}

Abidin, M. J. Z., Mohammadi, Pour-M., \& Alzwari, H. (2012). EFL students' attitudes towards learning English language: The case of Libyan secondary school students. Asian Social Science, 8(2), 119-134. https://doi.org/10.5539/ass.v8n2p119

Adeoye, F. A. (2000). Assessment procedure and students' gender as determinants of performance on hierarchical cognitive level in physics, published doctoral dissertation, faculty of social sciences, university of Ibadan. Ibadan, Nigeria.

Adesoji, F. A., \& Raimi, S. M. (2004). Effects of enhanced laboratory instructional technique on senior secondary students' attitude toward chemistry in Oyo Township, Oyo State, Nigeria. Journal of Science Education and Technology, 13(3), 377-385.

Adey, P., \& Shayer, M. (1994). Really raising standards. Routledge.

Aiken, L. R., \& Aiken, D. R. (1969). Recent research on attitudes concerning science. Science Education, 53(4), 295-305. https://doi.org/10.1002/sce.3730530405

Amina, A. M. (2016). Self-concept, locus of control and school motivation in relation to academic achievement among secondary school students in northern Nigeria published doctoral dissertation, school of education, university of Leicester, England, UK.

Anditi, Z. O., \& Okere, M. (2013). Influence of school characteristics on the achievement of secondary school Chemistry students in the cognitive science process skill of evaluation in Kenya. European Journal of Educational Research, 2(4), 171-183.

Arslan, M. U., \& Akbarov, A. (2012). EFL learners' perceptions and attitudes towards English for the specific purposes. Acta Didactica Napocensia, 5(4), 25-30.

Barab, S. A., \& Luehmann, A. L. (2003). Building sustainable science curriculum: Acknowledging and accommodating local adaptation. Science Education, 87(4), 454-467.

Barmby, P., Kind, P. M., \& Jones, K. (2008). Examining changing attitudes in secondary school science. International Journal of Science Education, 30(8), 1075-1093.

Barnes, G., McInerney, D. M., \& Marsh, H. W. (2005). Exploring sex differences in science enrolment intentions: An application of the general model of academic choice. Australian Educational Researcher, 32(2), 1-23. https://doi.org/10.1007/BF03216817

Barton, A. C. (2001). Science education in urban settings: Seeking new ways of praxis through critical ethnography. Journal of Research in Science Teaching, 38(8), 899-917.

Bauer, C. F. (2002). What students think: College students describe their high school chemistry class. Science Teacher, 69(1), 52-55.

Bennett, J. (2001). The development and use of an instrument to assess students' attitude to the research of chemistry. International Journal of Science Education, 23(8), 833-845. https://doi.org/10.1080/09500690010006554

Bryman, A. (2012). Social research methods (4th ed.). Oxford, New York, NY: Oxford University Press.

Burns, N., Grove, S. K. (2005). The practice of nursing research: Conduct, critique, and utilization (5th ed.). Elsevier Saunders.

Capaldi, E. J., \& Proctor, R. W. (2005). Current and future trends in experimental psychology. Handbook of research methods in experimental psychology. Blackwell.

Cheung, D. (2009). Students' attitudes toward chemistry lessons: The interaction effect between grade level and gender. Research in Science Education, 39(1), 75-91. 
Cohen, L., Manion, L., \& Morrison, K. (2007). Research methods in education (6th ed.). Routledge.

Corder, G. W., Foreman, D. I. (2009). Nonparametric statistics for non-statisticians: A step-by-step approach (2nd ed.). John Wiley \& sons.

de Vos, W., Bulte, A. M. W., \& Pilot, A. (2002). Chemistry curricula for general education: Analysis and elements of a design. In J. Gilbert, Onno, D., Jong, R., Justi, D. F., Treagust \& J. V. Driel (Eds.), Chemical education: Towards research-based practice (pp. 101-124). Kluwer Academic Publishers.

Dehbozorgi, E. (2012). Effects of attitude towards language learning and risk-taking on EFL students' proficiency. International Journal of English Linguistics, 2(2), 41-48.

Dornyei Z. (1990). Conceptualizing motivation in foreign-language learning. Language Learning, 40(1), 45-75.

Durant, J. R., Evans, G. A., \& Thomas, G. P. (1989). The public understanding of science. Nature, $340,11-14$.

Eagly, A. H., \& Chaiken, S. (1998). Attitude structure and function. In D. T. Gilbert, S. T. Fiske, \& G. Lindzey (Eds.), The handbook of social psychology (Vol. 1, pp. 269-322, 4th ed.). McGraw-Hill.

Eflin, J. T., Glennan, S., \& Reisch, G. (1999). The nature of science: A perspective from the philosophy of science. Journal of Research in Science Teaching, 36(1), 107-116.

Elliott, A. C., \& Woodward, W. A. (2007). Statistical analysis quick reference guidebook: With SPSS examples. Sage.

Eze, U. N., \& Agboma, V. U. (2008). Relationship between science teachers perceived self-efficacy and job performance. International Journal of Education and Research, 8(1), 162-170.

Festus, C. (2012). Improving students' performance and attitude towards chemistry through problembased-solving techniques (PBST). International Journal Academic Research in Progressive Education and Develop, 1(1), 167-174.

Finch, A. (2008). An attitudinal profile of EFL learners in Korea. Electronic Journal of Foreign Language Teaching, 5(2), 206-219.

Friedler, Y., \& Tamir, P. (1990). Sex differences in science education in Israel: An analysis of 15 years of research. Research in Science and Technological Education, 8(1), 21-34. https://doi. org $/ 10.1080 / 0263514900080103$

Fusco, D. (2001). Creating relevant science through urban planning and gardening. Journal of Research in Science Teaching, 38(8), 860-877. https://doi.org/10.1002/tea.1036

Gardner, P. L. (1975). Science curricula and attitudes to science: A Review. Australian Science Teachers Journal, 21(2), 23-40.

Gilbert, J. K. (2006). On the nature of context in chemical education. International Journal of Science Education, 28(9), 957-976. https://doi.org/10.1080/09500690600702470

Glasman, L. R., \& Albarracín, D. (2006). Forming attitudes that predict future behavior: A meta-analysis of the attitude-behavior relation. Psychological Bulletin, 132(5), 778-822. https://doi.org/10.1037/0033-2909.132.5.778

Government of Pakistan. (1959). National Commission on Education 1959. Karachi: Ministry of Education.

Government of Pakistan. (1992). National Education Policy 1992. Islamabad: Ministry of Education.

Government of Pakistan. (1998-2010). Education Policy 1998-2010. Islamabad: Ministry of Education.

Government of Pakistan. (2009). National Education Policy 2009. Islamabad: Ministry of Education.

Gräber, W. (2002). Chemistry education's contribution to scientific literacy-An example. Research in Chemical Education: What does this mean, 119-128. Aachen: Shake.

Grandy, R., \& Duschl, R. A. (2007). Reconsidering the character and role of inquiry in school science: Analysis of a conference. Science and Education, 16(1), 141-166. https://doi.org/10.1007/s11191-005-2865-z 
Haney, J. J., \& McArthur, J. (2002). Four case studies of prospective science teachers' beliefs concerning constructivist teaching practices. Science Education, 86(6), 783-802. https://doi.org/10.1002/sce. 10038

Harvey, T. J., \& Stables, A. (1986). Gender differences in attitudes to science for third year pupils: An argument for single-sex teaching groups in mixed schools. Research in Science and Technological Education, 4(2), 163-170. https://doi.org/10.1080/0263514860040206

Hassan, M. Ul., \& Akbar, R. A. (2016). Attitudes and practices of secondary school students about information communication technology: A comparison by gender, locale and subjects of research. Journal of Educational Research, 19(1), 24-38.

Hofstein, A., \& Kesner, M. (2006). Industrial chemistry and school chemistry: Making chemistry studies more relevant. International Journal of Science Education, 28(9), 1017-1039. https://doi.org/10.1080/09500690600702504

Hofstein, A., \& Mamlok-Naaman, R. (2011). High-school students' attitudes toward and interest in learning chemistry. Chemical Education, 22(2), 90-102.

Hofstein, A., Ben-zvi, R., Samuel, D., \& Tamir, P. (1977). Attitudes of Israeli high-school students toward Chemistry and Physics: A comparative research. Science Education, 61(2), 259-268. https://doi.org/10.1002/sce.3730610217

Hofstein, A., Shore, R., \& Kipnis, M. (2004). Providing high school chemistry students with opportunities to develop learning skills in an inquiry-type laboratory: A case study. International Journal of Science Education, 26(1), 47-62.

Holbrook, J. (2005). Making chemistry teaching relevant, Chemical Education International, 6(1), $1-12$.

Holbrook, J., \& Rannikmae, M. (2007). The nature of science education for enhancing scientific literacy. International Journal of Science Education, 29(11), 1347-1362. https://doi.org/10.1080/09500690601007549

Iqbal, H. M. (1997). A research on the effectiveness of intervention methodology on the cognitive development of science students, published doctoral dissertation, Institute of education and research, university of the Punjab, Lahore Pakistan.

Iqbal, H. M., Azam, S., \& Rana, R. A. (2009). Secondary school science teachers' views about the 'nature of science', Bulletin of Education and Research, 31(2), 29-44.

Jenkins, E. W. (1994). Public understanding of science and science education for action. Journal of Curriculum Studies, 26(6), 601-612.

Kahle, J. B. (1994). Research on gender issues in the classroom. Handbook of research on science teaching and learning. Macmillan.

Kaiser, F. G., \& Schultz, P. W. (2009). The attitude-behavior relationship: A test of three models of the moderating role of behavioral difficulty. Journal of Applied Social Psychology, 39(1), 186-207. https://doi.org/10.1111/j.1559-1816.2008.00435.x

Khalick, Abd-El-F., \& Lederman, N. G. (2000). Improving science teachers' conceptions of nature of science: A critical review of the literature. International Journal of Science Education, 22(7), 665-701. https://doi.org/10.1080/09500690050044044

Khalick, Abd-El-F., Bell, R. L., \& Lederman, N. G. (1998). The nature of science and instructional practice: Making the unnatural natural. Science Education, 82(4), 417-436.

Kind, P. M., Jones, K., \& Barmby, P. (2007). Developing attitudes towards science measures. International Journal of Science Education, 29(7), 871-893. https://doi.org/10.1080/09500690600909091

Koballa, T. R., \& Crawley, F. E. (1985). The influence of attitude on science teaching and learning. School Science and Mathematics, 85(3), 222-232. https://doi.org/10.1111/j.1949-8594.1985.tb09615.x

Koch, J. (2005). Science stories: science methods for elementary and middle school teachers. (3rd ed.). Houghton Miffian Company.

Lederman, N. G., Khalick, Abd-El-F., Bell, R. L., \& Schwartz, R. S. (2002). Views of nature of science questionnaire (VNOS): Toward valid and meaningful assessment of learners' conceptions of nature of science. Journal of Research in Science Teaching, 39(6), 497-521. https://doi.org/10.1002/tea.10034 
Michie, M., Hogue, M., \& Rioux, J. (2018). The application of both-ways and two-eyed seeing pedagogy: Reflections on engaging and teaching science to post-secondary indigenous Students. Research in Science Education, 48(6), 1205-1220.

Miller, J. D., Pardo, R., \& Niwa, F. (1997). Public perceptions of science and technology: A comparative research of the European Union, the United States, Japan, and Canada Bilbao: BBV Foundation.

Murphy, P., \& Whitelegg, E. (2006). Girls and physics: Continuing barriers to 'belonging'. The Curriculum Journal, 17(3), 281-305. https://doi.org/10.1080/09585170600909753

Noels, K. A., Pelletier, L. G., Clément, R., \& Vallerand, R. J. (2000). Why are you learning a second language? Motivational orientations and self-determination theory. Language Learning, 50(1), 57-85. https://doi.org/10.1111/1467-9922.53223

Osborne, J., \& Collins, S. (2001). Pupils' views of the role and value of the science curriculum: A focus group research. International Journal of Science Education, 23(5), 441-467. https://doi.org/10.1080/09500690010006518

Osborne, J., \& Dillon, J. (2008). Science education in Europe: Critical reflections. London: The Nuffield Foundation.

Osborne, J., Simon, S., \& Collins, S. (2003). Attitudes towards science: A review of the literature and its implications. International Journal of Science Education, 25(9), 10491079. https://doi.org/10.1080/0950069032000032199

Öztuna, D., Elhan, A. H., \& Tüccar, E. (2006). Investigation of four different normality tests in terms of type 1 error rate and power under different distributions. Turkish Journal of Medical Sciences, 36(3), 171-176.

Raimi, S. M. (1999, April). Gender differences among college students as determinant of performance in integrated science. Paper Presented at the National Conference on Teacher Education in the 21 st century. Kwara College of Education: Ilroin, Nigeria.

Raimi, S. M. (2002). Problem solving technique and laboratory skills as supplements to laboratory teaching in senior secondary school students' learning of volumetric analysis, published doctoral dissertation, faculty of social sciences, university of Ibadan, Ibadan, Nigeria.

Rashid, M. M., \& Gao, Q. (2012). Determinant's of rural youth's attitude and involvement in Bangladesh politics. International Journal of Humanities and Social Sciences, 2(23), 183193.

Salta, K., \& Tzougraki, C. (2004). Attitudes toward chemistry among 11th grade students in high schools in Greece. Science Education, 88(4), 535-547. https://doi.org/10.1002/sce.10134

Scheaffer, R., \& Smith, W. B. (2007). Using statistics effectively in mathematics education research: A report from a series of workshops organized by the American Statistical Association with funding from the National Science Foundation. Alexandria, VA: American Statistical Association.

Shannon, A. G., Sleet, R. J., \& Stern, W. (1982). School students' attitudes to science subjects. Australian Science Teachers Journal, 28(1), 77-82.

Singh, A. S., \& Masuku, M. B. (2014). Normality and data transformation for applied statistical analysis, International Journal of Economics, Commerce and Management, 2(7), 1-11.

Sirhan, G. (2007). Learning difficulties in chemistry: An overview, Journal of Turkish Science Education, 4(2), 2-20.

Smithers, A., \& Robinson, P. (1988). The growth of mixed A-levels, Department of Education, University of Manchester, Manchester.

Spillane, J. P., Diamond, J. B., Walker, L. J., Halverson, R., \& Jita, L. (2001). Urban school leadership for elementary science instruction: Identifying and activating resources in an undervalued school subject. Journal of Research in Science Teaching, 38(8), 918-940. https://doi.org/10.1002/tea.1039

Stanovich, K. E. (2003). Understanding the styles of science in the research of reading. Scientific Studies of Reading, 7(2), 105-126.

Stark, R., \& Gray, D. (1999). Gender preferences in learning science. International Journal of Science Education, 21(6), 633-643. 
Steinkamp, M. W., \& Maehr, M. L. (1984). Gender differences in motivational orientations toward achievement in school science: A quantitative synthesis. American Educational Research Journal, 21(1), 39-59. https://doi.org/10.3102/00028312021001039

Taber, K. S. (2018). The use of Cronbach's alpha when developing and reporting research instruments in science education. Research in Science Education, 48(6), 1273-1296. https://doi.org/10.1007/s11165-016-9602-2

Urban, H. (2008). Lessons from the classroom. Great Lessons Press.

Usman, K. O., \& Memeh, I. M. (2007). Using guided scoring teaching strategy to improve students' achievement in Chemistry at secondary school level in Nigeria. Journal of the Science Teachers Association of Nigeria, 42(2), 60-65.

Usman. K. O., \& Uba, A. I. (2007). Improving students' achievement in further Chemistry using team teaching approach. Review of Education, 18(1), 15-21.

Warrington, M., \& Younger, M. (2000). The other side of the gender gap. Gender and Education, 12(4), 493-508.

Wong, A. F. L., \& Fraser, B. J. (1996). Environment-attitude associations in the chemistry laboratory classroom. Research in Science and Technological Education, 14(1), 91-102.

Yara, P. O. (2009). Students' attitude towards mathematics and academic achievement in some selected secondary schools in Southwestern Nigeria. European Journal of Scientific Research, 36(3), 336-341.

Received 02 March 2020; Accepted 21 June 2020

Cite as: Hassan, M. U1., \& Murtaza, A. (2020). Secondary school students' attitudes towards learning chemistry: Comparison by gender, age and educational stream. Gamtamokslinis ugdymas / Natural Science Education, 17(1), 7-23.

\section{Mehboob UI Hassan}

$\mathrm{PhD}$, Institute of Education and Research, University of the Punjab, Lahore, Pakistan.

E-mail: hassanbhattig@hotmail.com

\section{Ammara Murtaza}

$\mathrm{PhD}$, Institute of Education and Research, University of the Punjab, Lahore, Pakistan.

E-mail: ammara.murtaza14@gmail.com 